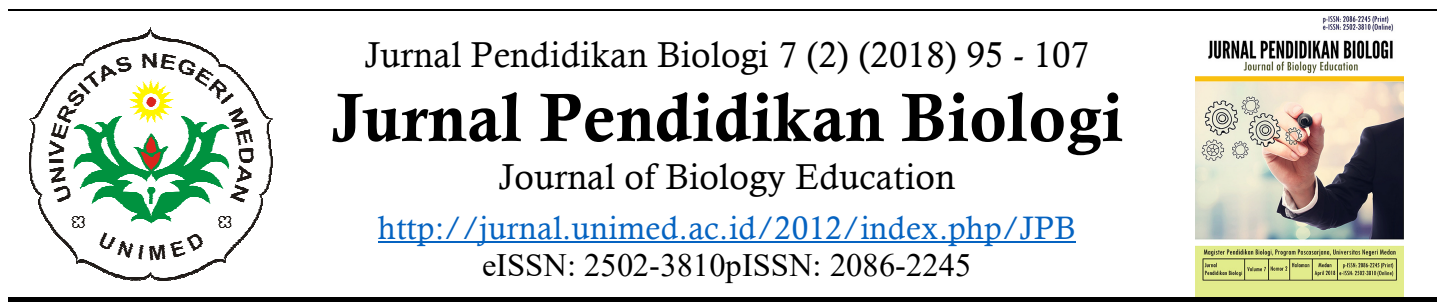

\title{
Pengembangan Lembar Kerja Mahasiswa Berbasis Search, Solve, Create, and Share pada Praktikum Mandiri Mata Kuliah Ekologi Hewan
}

\author{
Nurhidaya Fithriyah Nasution* \\ Pendidikan Biologi, Institut Pendidikan Tapanuli Selatan \\ *Korespondensi: nst.fithri@gmail.com
}

\begin{abstract}
ABSTRAK
The purpose of this research was to develop and know the effectiveness of student's work sheet based on Search, Solve, Create, and Share in Animal Ecology. This research was designed in Research and Development (R\&D) research where the method was used to produce the certain product. The develop of learning devices in this research use the Research and Development research developed by Thiagarajan, et al. (1974). This research was tested in STKIP Tapanuli Selatan semester VB. The result of expert assessment to student's work sheet based on search, solve, create, and share showed the student's work sheet of development result was reasonable used in learning with the percentage of reasonable aspect obtained $76,96 \%$. The test result showed that student's work sheet based on search, solve, create, and share was effective in learning. The average value of $\mathrm{N}$-gain was 0,65 with medium category showed that there was an improvement of learning outcomes from pretest to posttest. The average percentage of thinking skill and activity of students in sequent was $72,77 \%$ and $74,87 \%$. Based on the research result, the develop of student's work sheet based on search, solve, create, and share was reasonable and effective applied in Animal Ecology subject.
\end{abstract}

Keyword: Independent Lab The Develop of Student's Work Sheet, Search, Solve, Create, and Share model.

\section{PENDAHULUAN}

Proses belajar mengajar akan berjalan efektif dan efisien bila didukung dengan tersedianya bahan ajar atau alat bantu yang menunjang. Penyediaan bahan ajar serta metodologi pendidikan yang dinamis, kondusif serta dialogis sangat diperlukan bagi pengembangan potensi mahasiswa secara optimal. Potensi mahasiswa akan muncul bila dibantu dengan sejumlah bahan ajar atau alat bantu yang mendukung proses interaksi yang sedang dilaksanakan. Dosen selain menggunakan buku-buku teks untuk menggali potensi mahasiswa, juga mulai mengenalkan adanya lembar-lembar pembelajaran mahasiswa (student learning sheet) dengan 
nama yang bermacam-macam, yaitu: 1) lembar tugas mahasiswa (student task sheet), 2) lembar kerja mahasiswa (student job sheet), 3) lembar informasi mahasiswa (student information sheet), dan bahan ajar lainnya baik cetak maupun non cetak.

Perkuliahan yang dilaksanakan pada mata kuliah Ekologi Hewan sudah mengacu kepada pembelajaran yang berpusat kepada mahasiswa (student centered learning), dimana mahasiswa senantiasa dilibatkan dalam memperoleh dan mengolah informasi terutama dalam mempresentasikan materi perkuliahan. Bruner menyatakan bahwa tiga proses berlangsung bersamaan ketika siswa belajar yaitu memperoleh informasi, mentransformasi informasi dan menguji relevansi serta ketepatan pengetahuan dengan kehidupan sehari-hari. Dosen pengampu matakuliah berupaya menggunakan berbagai pendekatan, strategi dan model pembelajaran yang berpusat pada mahasiswa agar mahasiswa dapat mencapai tujuan pembelajaran seperti yang sudah dijabarkan dari kompetensikompetensi dasar sesuai silabus.

Mata kuliah Ekologi Hewan merupakan salah satu matakuliah wajib bagi mahasiswa program Studi Pendidikan Biologi di STKIP Tapanuli Selatan, dengan alokasi waktu 4 SKS, mahasiswa dituntut agar memiliki kompetensi dapat memahami, melatih mahasiswa untuk belajar sains mulai dari menemukan masalah sampai menggambarkan kesimpulan tentang masalah ilmiah. Dengan menerapkan model pembelajaran Model Search, Solve, Create, and Share akan dikembangkan LKM dalam matakuliah Ekologi Hewan sehingga di akhir perkuliahan mahasiswa diharapkan mampu memahami, menerapkan serta mengaplikasikan sasaran dan strategi serta permodelan-permodelan dalam Ekologi
Hewan dalam kehidupan sehari-hari dengan benar.

Model Search, Solve, Create, and Share (SSCS) merupakan salah satu model pembelajaran yang mengarahkan siswa untuk mengkonstruksi pengetahuan, artinya dapat diterapkan dengan pendekatan konstruktivistik dan metode pembelajaran problem solving. Pembelajaran menggunakan model SSCS, dosen dan mahasiswa bekerja sama untuk mencari solusi terhadap suatu masalah, sehingga pembelajaran akan lebih bermakna bagi siswa. Pembelajaran bermakna bagi siswa merupakan prinsip dari teori belajar kontruktivisme. Proses belajar yang berlandaskan pada teori belajar kontruktivis menurut Pribadi (2009), dilakukan dengan memfasilitasi siswa agar memperoleh pengalaman belajar yang digunakan untuk membangun makna terhadap pengetahuan yang dipelajari.

Model Search, Solve, Create and Share (SSCS) merupakan model berpendekatan pemecahan masalah yang terdiri dari empat tahap yaitu mengidentifikasi, membuat hipotesis, melakukan pengamatan, dan mengkomunikasikan. LKM berbasis model SSCS diterapkan pada praktikum mandiri, yaitu kegiatan yang dilakukan mahasiswa secara mandiri untuk melakukan pengamatan, perencanaan, penyelidikan dalam rangka memecahkan permasalahan. Berdasarkan dari hal tersebut, model SSCS merupakan model pembelajaran yang dapat diaplikasikan secara nyata dalam pembelajaran.

Dalam dua tahun terakhir pengampu matakuliah, berupaya melaksanakan proses perkuliahan dengan melibatkan mahasiswa secara langsung untuk memperoleh berbagai informasi mengenai ruang lingkup materi perkuliahan. Mahasiswa sudah ditugaskan untuk mempersiapkan makalah secara berkelompok dan saat tatap muka di kelas dosen memberi kesempatan untuk 
mempresentasikan tugas dan berdiskusi dengan kelompok lain. Strategi yang diterapkan cukup efektif untuk mengaktifkan mahasiswa, namun dengan alokasi waktu tatap muka 4 × 50 menit, mahasiswa belum dapat berlatih dalam melakukan pengamatan, perencanaan, penyelidikan dalam rangka memecahkan masalah percobaan yang merupakan implementasi dari teori-teori yang diperoleh selama perkuliahan.Untuk itu perlu dilakukan pengembangan perangkat LKM dengan mengacu pada metode penelitian pengembangan yang akan digunakan untuk menghasilkan produk tertentu dan menguji efektifitasnya (Sugiyono, 2008). Pada tahap ini dosen pengampu bermaksud untuk menghasilkan perangkat LKM berbasis Model Search, Solve, Create, and Share pada praktikum mandiri. Pengembangan LKM dilakukan sampai tahap mengembangkan produk awal (Develop preliminary form of product). Langkah penelitian ini mengacu pada strategi yang dikembangkan oleh Thiagarajan, et al. (1974). Penelitian ini bertujuan untuk mengembangkan perangkat pembelajaran yakni LKM berbasis Model Search, Solve, Create, and Share pada praktikum mandiri yang dipersiapkan untuk pelaksanaan matakuliah Ekologi Hewan berupa prototipe LKM yang praktis dan valid akan divalidasi secara internal dan eksternal serta siap untuk diujicobakan.

\section{METODE PENELITIAN}

Penelitian ini akan dilaksanakan di STKIP Tapanuli Selatan, Jln. Stn. Mhd. Arif Kel. Batang Ayumi Jae Kota Padangsidimpuan. Waktu penelitian dilakukan pada semester ganjil tahun pembelajaran 2016/2017 bulan SeptemberFebruari 2017.Populasi dalam penelitian ini adalah mahasiswa Semester V STKIP Tapanuli Selatan. Sampel yang diambil dalam penelitian ini berjumlah 31 mahasiswa. Sampel penelitian ini diambil atau ditentukan dengan teknik Purposive Sampling.

Penelitian ini dirancang sebagai penelitian Research and Development (R\&D) yang merupakan desain penelitian dan pengembangan yaitu metode penelitian yang digunakan untuk menghasilkan produk tertentu. Pengembangan perangkat pembelajaran dalam penelitian ini menggunakan penelitian pengembangan dikembangkan oleh Thiagarajan, et al. (1974). Model ini terdiri dari 4 tahap pengembangan, yaitu define, design, develop, dan desseminate atau diadaptasikan menjadi pendefinisian, perancangan, pengembangan, dan penyebaran. Dalam penelitian ini akan dikembangkan perangkat perkuliahan berupa lembar kerja mahasiswa berbasis Model Search, Solve, Create, and Share pada praktikum mandiri dan penelitian yang dilakukan hingga pada tahap desseminate (penyebaran).

Adapun instrumen yang digunakan dalam penelitian ini adalah sebagai berikut:

\section{Lembar Validasi LKM}

Instrumen yang digunakan untuk memvalidasi LKM oleh tenaga ahli adalah berbentuk angket. Angket tersebut berisi pertanyaan tentang kelayakan isi, kebahasaan, dan penyajian LKM berbasis model Search, Solve, Create and Share.

\section{Lembar Uji Efektivitas LKM \\ Lembar Tes Hasil Belajar}

Tes ini dilaksanakan pada akhir perkuliahan untuk mengetahui tingkat kemampuan mahasiswa dalam perkuliahanan ekologi hewan. Tes ini juga berfungsi untuk mengetahui tingkat keefektifan LKM yang dikembangkan. Tes 
diberikan kepada mahasiswa sebanyak dua kali. Tes tersebut berupa pretest dan posttes.

\section{Lembar Observasi Keterampilan Berpikir Mahasiswa}

Keterampilan berpikir pada saat mahasiswa mengerjakan LKM dapat diamati melalui kegiatan tahap Search, Solve, Create, and Share, antara lain sebagai berikut.

- Tahap Search yaitu kemampuan mahasiswa untuk mengidentifikasi masalah yang diberikan.

- Tahap Solve yaitu kemampuan mahasiswa menyusun hipotesis berupa dugaan jawaban dari masalah dan memilih metode untuk memecahkan masalah.

- Tahap Create yaitu kemampuan mahasiswa melakukan kegiatan untuk membuktikan hipotesis, mengolah dan menganalisis hasil kegiatan pengamatan.

- Tahap Share yaitu kemampuan mahasiswa mengidentifikasi kesimpulan pemecahan masalah dan mengkomunikasikan hasil atau solusi yang diperoleh dari kegiatan pengamatan.

\section{Lembar Observasi Aktivitas Mahasiswa}

Aktivitas mahasiswa yang dapat diamati pada saat pembelajaran menggunakan LKM berbasis Search, Solve, Create, and Share meliputi memperhatikan dosen, kerjasama dalam kelompok, aktivitas mahasiswa dalam diskusi kelompok, kemampuan mahasiswa mengemukakan pendapat atau menjawab pertanyaan dari dosen/teman, aktivitas mahasiswa dalam bertanya kepada dosen/teman dan aktivitas mahasiswa dalam mengikuti diskusi/presentasi.

Teknik analisis data yang digunakan adalah teknik analisis data deskriptif. Teknik analisis deskriptif dilakukan dengan menggunakan statistik deskriptif. Statistik deskriptif ini adalah statistik yang digunakan untuk menganalisis data dengan cara mendeskripsikan atau menggambarkan data yang telah terkumpul sebagaimana adanya tanpa bermaksud membuat kesimpulan yang berlaku untuk umum atau generalisasi. Analisis data hasil penelitian dilakukan untuk mengetahui validitas dan efektivitas LKM yang telah dibuat. Efektifitas LKM meliputi hasil belajar, aktivitas, dan keterampilan berpikir mahasiswa.

\section{HASIL DAN PEMBAHASAN}

\section{Hasil Penelitian}

Hasil analisis kebutuhan terhadap LKM, 81.08\% responden menyatakan perlu menggunakan LKM dan 89,19\% setuju bila dalam pembelajaran ekologi hewan menggunakan metode praktikum. Berdasarkan hasil analisis angket kebutuhan LKM, disimpulkan bahwa perlu adanya pengembangan LKM dan penggunaan metode praktikum dalam pembelajaran ekologi hewan.

Hasil angket analisis kebutuhan mahasiswa dijadikan acuan untuk mengembangan Lembar Kerja Mahasiswa berbasis Search, Solve, Create, and Share pada mata kuliah ekologi hewan. Hal tersebut sejalan dengan Setyosari (2010) yang menjelaskan bahwa analisis kebutuhan dilakukan pada awal sebelum produksi produk. Berdasarkan analisis, disusunlah draf LKM untuk dilakukan validasi, uji coba lapangan, direvisi atau disempurnakan, dan sampai menjadi produk akhir.

\section{Tahap Perancangan}

Pada tahap perancangan terdiri dari pembuatan kisi-kisi instrumen penelitian yang menjadi kriteria penilaian LKM berbasis Model Search, Solve, Create, and Share pada praktikum mandiri. Kisi-kisi ini 
kemudian dikembangkan menjadi instrumen penelitian. Intrumen penelitian yang digunakan terdiri dari lembar validasi LKM dan rencana pembelajaran semester (RPS), lembar validasi tes akhir, lembar kemampuan berpikir mahasiswa, dan lembar aktivitas mahasiswa.

Kelayakan LKM divalidasi oleh validator yang merupakan teman sejawat peneliti. Validator dalam penelitian ini terdiri dari 2 orang dosen program studi pendidikan Biologi STKIP Tapanuli Selatan dan 1 orang dosen program studi pendidikan Biologi Universitas Labuhan Batu yang mempunyai latar belakang yang sesuai dengan penelitian ini. Validasi terhadap LKM dilakukan dengan tujuan untuk mendapatkan informasi, kritik, dan saran dari validator agar LKM berbasis Model Search, Solve, Create, and Share pada praktikum mandiri dapat dikembangkan menjadi produk yang berkualitas baik dari segi aspek materi, penyajian, serta bahasa dan keterbacaan.

\section{Pengembangan}

Pengembangan LKM berbasis Search, Solve, Create, and Share (SSCS) pada mata kuliah ekologi hewan menggunakan aplikasi software Microsoft Office 2007, yaitu aplikasi Microsoft Word. Penelitian pengembangan LKM berbasis SSCS menggunakan ukuran kertas A4 dengan orientasi kertas potrait. Rancangan desain LKM berbasis SSCS dimulai dengan menyusun halaman cover, pendahuluan, dan petunjuk belajar.

Materi yang disajikan dalam LKM hanya materi yang terkait dengan kegiatan praktikum pada mata kuliah ekologi hewan. Materi berisi tentang Adaptasi Struktural Hewan Terhadap Lingkungan; Preferensi Pakan; Pola Pembagian Niche Oleh Serangga; Kompetisi Intraspesifik; Rantai Makanan, Tingkat Trofik, dan
Aliran Energi; Kerapatan Populasi dan KeanekaragamanFauna Tanah; Keanekaragaman Serangga Nokturnal.

Bagian kegiatan LKM berbasis SSCS, yaitu kegiatan tahap Search, tahap Solve, tahap Create, dan tahap Share. Tahap Search, yaitu kegiatan mengidentifikasi permasalahan dan memecahkan masalah berupa menjawab pertanyaan tentang materi yang dipraktikumkan. Masalah yang diidentifikasi mahasiswa dalam kegiatan tahap search yaitu pertanyaan yang terdapat dalam wacana tersebut.Tahap Solve, yaitu kegiatan membuat hipotesis atau dugaan jawaban dari pertanyaan pada tahap search, mahasiswa dituntut berpikir untuk menjawab pertanyaan. Selanjutnya, mahasiswa membuktikan jawabannya dengan melakukan pengamatan langsung yang tercantum dalam wacana tahap Search.

Tahap Create, yaitu kegiatan melakukan pengamatan serta membuat dokumentasi berupa foto ataupun video mengenai pengamatan tersebut. Tahap Create, mahasiswa melakukan pengamatan langsung dan membandingkan persamaan maupun perbedaan permasalahan yang tercantum dalam tahap Search. Selain itu,mahasiswa melengkapi tabel pengamatan pada tahap Create dalam LKM dan mendokumentasikan pengamatan tersebut. Tahap Share, yaitu kegiatan mengkomunikasikan hasil penyelidikan/pengamatan yang telah dilakukan pada tahap Create berupa laporan dan presentasi secara berkelompok.

Setelah LKM berbasis SSCS selesai dirancang maka dilakukan tahap validasi dengan tujuan untuk memperoleh kelayakan dari produk yang dihasilkan. Selanjutnya setelah LKM tersebut divalidasi, dilakukan tahap ujicoba terbatas penggunaan LKM berbasis SSCS dalam pembelajaran di kelas. Tahap ujicoba 
dilaksanakan pada mahasiswa semester VB STKIP Tapanuli Selatan, dengan tujuan untuk mengetahui respon mahasiswa terhadap LKM berbasis SSCS yang dikembangkan.

\section{Penyebaran}

Tahap terakhir dalam penelitian ini adalah tahap penyebaran (disseminate). Tahap ini dilakukan setelah semua produk divalidasi dan dinyatakan valid oleh validator. Produk yang telah valid akan disebarkan kepada mahasiswa semester VB STKIP Tapanuli Selatan yang akan mengambil mata kuliah ekologi hewan.

Berdasarkan hasil validasi, skor maksimum adalah 4 sedangkan skor minimum adalah 1. Jumlah skor kelayakan materi yang diperoleh dari ahli materi 1, 2, dan 3 yaitu 53, 50, dan 54. Skor total kelayakan materi 68 , sehingga persentase yang diperoleh dari ahli materi 1, 2, dan 3 yaitu 78\%, 73,5\%, dan 79,4\%, dengan kriteria "layak". Berdasarkan analisis diketahui bahwa rata-rata hasil penilaian kelayakan materi LKM oleh ketiga ahli sebesar $76,96 \%$ dengan kriteria "layak". Dapat disimpulkan bahwa LKM layak digunakan dalam pembelajaran namun masih perlu direvisi. Selanjutnya masukan dan saran dijadikan acuan untuk memperbaiki LKM agar diperoleh hasil yang baik.

\section{Efektivitas Lembar Kerja Mahasiswa \\ Kefektivan hasil belajar mahasiswa}

Pengambilan data hasil belajar secara individu dilakukan sebanyak dua kali yaitu sebelum (pretest) dan sesudah (posttest) pembelajaran menggunakan LKM berbasis Search, Solve, Create, and Share. Peningkatan nilai pretest-posttest disajikan dalam Gambar 1.

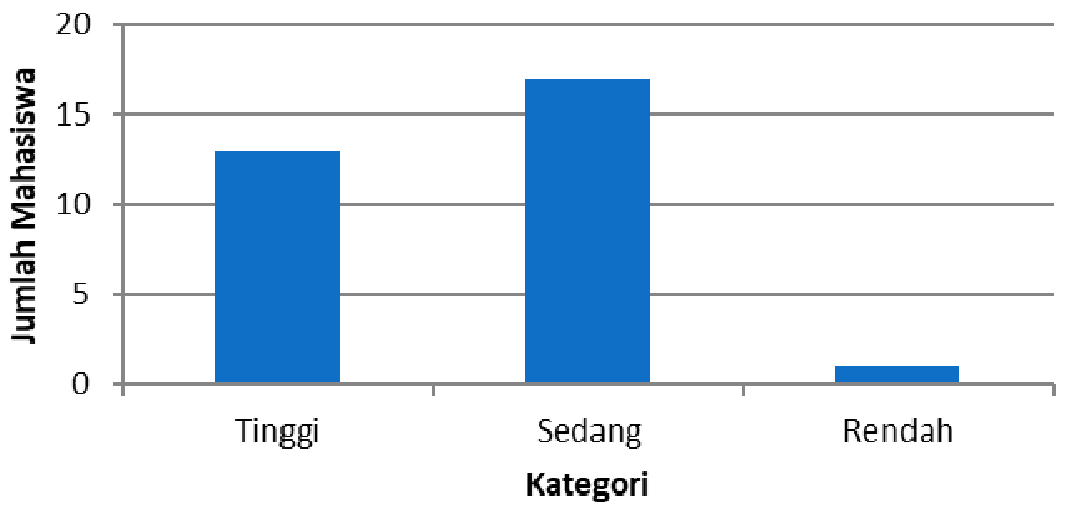

Gambar 1. Peningkatan Hasil Pretest-posttest

Berdasarkan Gambar 1 diperoleh hasil pembelajaran mengalami peningkatan hasil pretest-posttest. Berdasarkan hasil analisis pada data peningkatan hasil pretest-posttest menunjukkan bahwa hasil belajar mahasiswa mengalami peningkatan. Nilai rata-rata $N$-gain yaitu 0,65 dengan kategori sedang. Mahasiswa yang memperoleh peningkatan hasil pretest-posttest dengan kategori tinggi yaitu 13 orang, kategori sedang sebanyak 17 orang, dan kategori rendah sebanyak 1 orang. Hasil belajar mahasiswa sebagai nilai akhir merupakan akumulasi rata-rata nilai LKM dan nilai posttest. Data hasil belajar siswa disajikan pada Gambar 2. 
Nasution / Jurnal Pendidikan Biologi 7 (2) (2018) 95 - 107

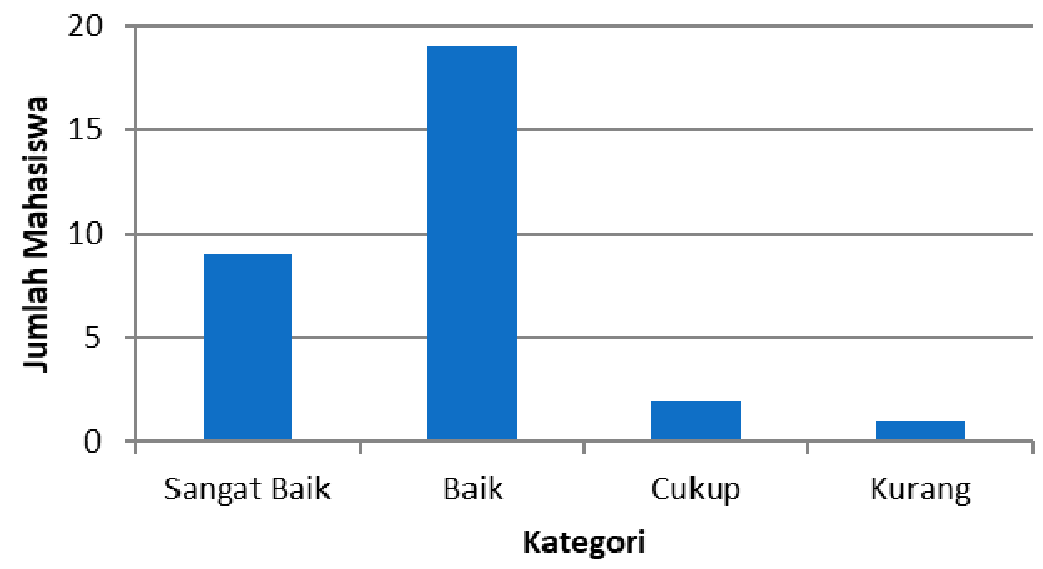

Gambar 2. Hasil Akhir Belajar setelah Menggunakan LKM Berbasis Model Search, Solve, Create, and Share pada Praktikum Mandiri

Berdasarkan Gambar 2,diperoleh hasil akhir mahasiswa yang merupakan akumulasi rata-rata nilai LKM dan nilai posttest. Berdasarkan hasil analisis data diperoleh mahasiswa yang berkategori sangat baik yaitu 9 orang, kategori baik sebanyak 19 orang, kategori cukup sebanyak 2 orang, dan kategori kurang sebanyak 1 orang. Pada grafik 1 dan 2 diketahui bahwa pembelajaran menggunakan LKM berbasis Search, Solve, Create, and Share menunjukkan hasil yang baik, dilihat dari rata-rata peningkatan skor pretest-posstest memiliki skor $N$-gain sebesar 0,65 kategori sedang dan rata-rata nilai hasil akhir secara klasikal mencapai 83,55 kategori baik.

\section{Data keterampilan berpikir mahasiswa}

Data keterampilan berpikir mahasiswa diambil dengan teknik observasi dalam pembelajaran Ekologi Hewan dengan menggunakan LKM berbasis Search, Solve, Create, and Share. Data keterampilan berpikir mahasiswa disajikan dalam Gambar 3.

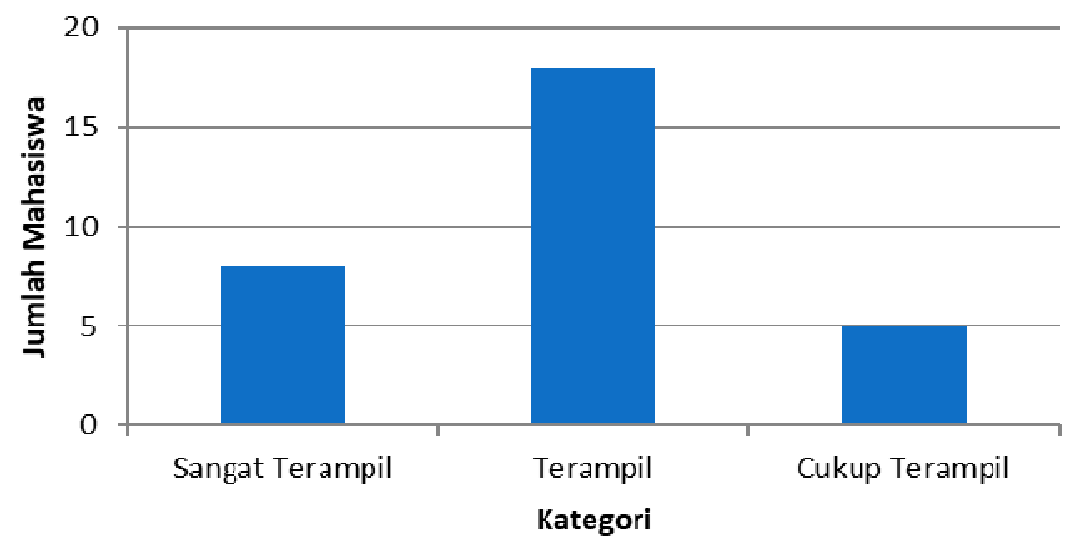

Gambar 3 Data Keterampilan Berpikir Mahasiswa

Berdasarkan Gambar 3, perolehan dengan kriteria sangat terampil sebanyak 8 nilai keterampilan berpikir mahasiswa orang, kategori terampil 18, dan kategori 
cukup terampil 5 orang. Keterampilan berpikir mahasiswa dalam pembelajaran menggunakan LKM berbasis Search, Solve, Create, and Share menunjukkan hasil yang baik. Hal tersebut ditunjukkan dengan ratarata persentase secara klasikal mencapai $72,77 \%$ kategori terampil.
Data Aktivitas Mahasiswa

Data aktivitas mahasiswa diambil dengan teknik observasi dalam pembelajaran Ekologi Hewan dengan menggunakan LKM berbasis Search, Solve, Create, and Share. Data aktivitas siswa disajikan dalam Gambar 4.

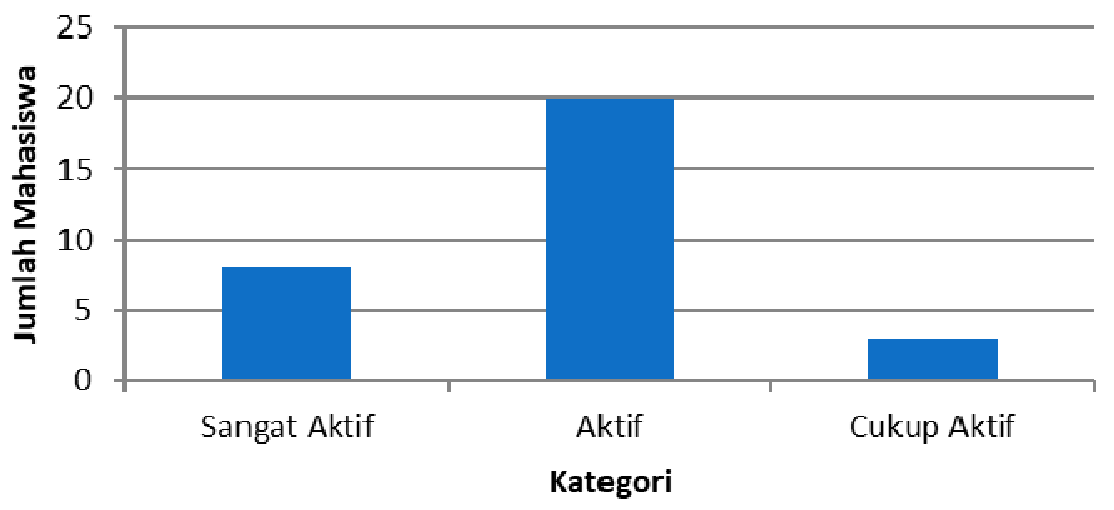

Gambar 4 Data Aktivitas Mahasiswa

Berdasarkan Gambar 4, perolehan nilai aktivitas mahasiswa dengan kriteria sangat aktifsebanyak 8 orang, kategori aktif 20, dan kategori cukup aktif 3 orang. Aktivitasmahasiswa dalam pembelajaran menggunakan LKM berbasis Search, Solve, Create, and Share menunjukkan hasil yang baik. Hal tersebut ditunjukkan dengan ratarata persentase secara klasikal mencapai $74,87 \%$ kategori aktif.

\section{Pembahasan}

Langkah awal dalam penelitian Research and Development (R\&D) adalah mengidentifikasi potensi dan masalah, dengan cara pengumpulan data melalui angket analisis kebutuhan kepada mahasiswa. Analisis kebutuhan LKM dilakukan pada 28 September 2016, dengan responden adalah mahasiswa semester VII A yang berjumlah 37mahasiswa. Angket analisis kebutuhan LKM berisi 14 pertanyaan.
Hasil angket analisis kebutuhan menunjukkan bahwa pada mata kuliah ekologi hewan selama ini belum pernah menggunakan LKM. Hal tersebut ditunjukkan dengan seluruh responden mengatakan belum pernah menggunakan LKM dalam pembelajaran ekologi hewan. Bahan ajar yang digunakan berupa bukubuku sumber dari beberapa penerbit dan referensi internet. Seluruh responden juga mengatakan sering menggunakan media internet untuk mencari materi ekologi hewan dan mengerjakan tugas yang diberikan dosen.

Pata kuliah Ekologi Hewan mahasiswa dituntut agar memiliki kompetensi dapat memahami, melatih mahasiswa untuk belajar sains mulai dari menemukan masalah sampai menggambarkan kesimpulan tentang masalah ilmiah. Dengan menerapkan model pembelajaran Model Search, Solve, Create, and Share akan dikembangkan LKM dalam matakuliah Ekologi Hewan sehingga di akhir 
perkuliahan mahasiswa diharapkan mampu memahami, menerapkan serta mengaplikasikan sasaran dan strategi serta permodelan-permodelan dalam Ekologi Hewan dalam kehidupan sehari-hari dengan benar. Menurut Choo et al. (2011) dan Prastowo (2012) menyatakan bahwa lembar kerja siswa terdiri atas serangkaian tugas dan informasi yang dirancang untuk membimbing siswa belajar mandiri dan memudahkan guru dalam melaksanakan pembelajaran.

Model Search, Solve, Create, and Share (SSCS) merupakan salah satu model pembelajaran yang mengarahkan siswa untuk mengkonstruksi pengetahuan, dimana guru dan siswa bekerja sama untuk mencari solusi terhadap suatu masalah, sehingga pembelajaran akan lebih bermakna bagi siswa. Pembelajaran bermakna bagi siswa merupakan prinsip dari teori belajar kontruktivisme. Proses belajar yang berlandaskan pada teori belajar kontruktivisme menurut Pribadi (2009), dilakukan dengan memfasilitasi siswa agar memperoleh pengalaman belajar yang digunakan untuk membangun makna terhadap pengetahuan yang dipelajari. Selain itu, model SSCS merupakan model pembelajaran yang dapat diaplikasikan secara nyata dalam pembelajaran.

LKM memuat kegiatan mahasiswa yang berbasis Search, Solve, Create, and Share (SSCS). Kegiatan tersebut didesain untuk melibatkan mahasiswa untuk berperan aktif dalam pembelajaran dan mampu menemukan konsep dalam materi pada mata kuliah Ekologi Hewan. Hal tersebut didukung oleh pernyataan Widjajanti (2008) dan Chin (1997) bahwa materi dalam LKS disajikan secara ringkas, kegiatan dalam LKS yang berbasis model SSCS dapat mengembangkan keterampilan berpikir, menekankan proses untuk menemukan konsep serta melibatkan siswasecara aktif misalnya melalui diskusi, latihan soal, pengamatan, dan percobaan sederhana.

Langkah kedua dari penelitian ini adalah tahap validasi. Tahap validasi dilakukan oleh ahli. Penilaian meliputi check list rentang skor 1-4 pada kesesuaian komponen kelayakan isi, kebahasaan, penyajian, dan kegrafisan. Hasil validasi LKM berbasis Search, Solve, Create, and Share telah memenuhi kriteria LKM yang baik, karena pada komponen kelayakan materi memberi rata-rata skor 3. Prastowo (2012) menyatakan bahwa bahan ajar berisi tiga aspek yaitu pengetahuan, keterampilan, dan sikap. LKS yang baik dapat menambah pengetahuan, melibatkan siswa dalam mengembangkan keterampilan dan mengembangkan sikap ilmiah.

Persentase rata-rata hasil penilaian kelayakan LKM oleh ketiga ahli materi sebesar 76,96 \% dengan kriteria "layak", yang artinya LKS tersebut sangat layak dikembangkan. Ahli juga memberikan saran dan masukan demi perbaikan LKM. Masukan dan saran dari ahli dijadikan acuan untuk memperbaiki LKM agar diperoleh hasil yang lebih baik.

Tahap terakhir dalam penelitian ini adalah tahap penyebaran (disseminate). Tahap ini dilakukan setelah semua produk divalidasi dan dinyatakan valid oleh validator. Produk yang telah valid akan disebarkan kepada mahasiswa semester VB STKIP Tapanuli Selatan yang akan mengambil mata kuliah ekologi hewan sebanyak 31 orang. Pengambilan data keefektivan LKM meliputi data hasil belajar, aktivitas, dan keterampilan berpikir.

Hasil belajar dapat diamati melalui perubahan mahasiswa setelah mengikuti proses pembelajaran materi Ekologi Hewan. Pengambilan data hasil belajar secara individu dilakukan sebanyak dua kali yaitu sebelum (pretest) dan sesudah (posttest) pembelajaran menggunakan LKM berbasis Search, Solve, Create, and Share. 
Hasil belajar dilihat dari selisih nilai pretest dan posttest yang dihitung dengan rumus $N$ gain. Perbedaan antara nilai pretest dan posttest diasumsikan sebagai efek dari penggunaan LKM berbasis Search, Solve, Create, and Share dalam pembelajaran materi Ekologi Hewan.

Berdasarkan hasil analisis menunjukkan bahwa hasil belajar mahasiswa mengalami peningkatan. Nilai rata-rata $N$-gain semester VB sebesar 0,65 dengan kategori sedang. Hal tersebut menunjukkan adanya peningkatan pemahaman materi setelah melalui proses pembelajaran. Peningkatan pemahaman materi merupakan akibat dari mahasiswa melakukan kegiatan pengamatan sendiri, sehingga pembelajaran yang dialami mahasiswa akan lebih bermakna. Hal tersebut sejalan dengan diungkapkan oleh Aqib (2013), bahwa belajar akan lebih bermakna jika siswa mengalami apa yang dipelajarinya, bukan sekedar mengetahui materi.

Penilaian hasil belajar sebagai nilai akhir merupakan akumulasi rata-rata nilai LKM dan nilai posttest. Penilaian LKM diperoleh dari hasil laporan yang dikerjakan secara berkelompok dan presentasi hasil pengamatan. Setiap anggota kelompok mendapatkan nilai yang sama. Untuk nilai evaluasi (posttest) diperoleh dari hasil belajar mahasiswa secara individu pada akhir pembelajaran.

Secara teoritis, penerapan LKM berbasis Search, Solve, Create, and Share berpengaruh terhadap hasil belajar mahasiswa. Hal tersebut sesuai dengan hasil penelitian yang dilakukan oleh Choo et al. (2011). Penelitian ini bertujuan untuk mengetahui keefektivan lembar kerja siswa dalam pembelajaran berbasis masalah terhadap hasil belajar siswa. Hasil penelitian menunjukkan bahwa adanya perbedaan yang signifikan antara tingkat pemahaman kelas eksperimen dan kelas kontrol, yaitu rata-rata hasil belajar kelas eksperimen lebih tinggi dari kelas kontrol, sehingga adanya keunggulan kelas eksperimen.

Rata-rata perolehan nilai LKM yang diperoleh kelas cukup baik yaitu dari 80-95. Hal tersebut menunjukkan perolehan hasil belajar yang baik dengan pembelajaran berkelompok. Pembelajaran berkelompok memfasilitasi mahasiswa untuk saling berdiskusi, berbagi informasi dan bertukar pendapat dalam menyelesaikan tugas maupun kegiatan secara bersama-sama, sehingga dapat memperoleh hasil belajar yang baik. Hal tersebut didukung dengan pernyataan Slavin (2011), bahwa dalam pembelajaran kelompok, di mana siswa terutama berkerja bersama untuk membantu satu sama lain menguasai informasi maupun menyelesaikan suatu tugas.

Nilai akhir merupakan akumulasi ratarata nilai LKM berbasis Search, Solve, Create, and Share dan nilai posttest. Berdasarkan analisis nilai akhir yaitu 83,55 dengan kategori baik. Perolehan nilai akhir tertinggi yaitu 92,5 dan nilai akhir terendah yaitu 50. Mahasiswa yang memperoleh nilai rendah dikarenakan kalkulasi antara nilai posttest dengan perolehan nilai LKM tidak memenuhi batas kategori nilai baik yaitu 76 . Nilai posttest hanya 30 sedangkan nilai LKM yang diperoleh 70 . Berdasarkan nilai akhir yang diperoleh yaitu 83,55 dengan kategori baik, yang artinya LKM berbasis Search, Solve, Create, and Share efektif terhadap hasil belajar pada pembelajaran Ekologi Hewan.

LKM berbasis Search, Solve, Create, and Share pada mata kuliah Ekologi Hewan menyajikan kegiatan-kegiatan antara lain yang melatih kemampuan berpikir mahasiswa, melakukan pengamatan dan mengkomunikasikan hasil pengamatan tertulis maupun lisan. Hal tersebut 
didukung dengan pernyataan Pizzini (Chin, 1997), bahwa SSCS merupakan sebuah model pembelajaran pemecahan masalah dimana adanya kegiatan mengidentifikasi dan mencari solusi sebuah masalah, sehingga pembelajaran terasa bermakna dan berkesan bagi siswa.

LKM berbasis Search, Solve, Create, and Share pada mata kuliah Ekologi Hewan dikerjakan secara berkelompok yang terdiri dari empat tahap kegiatan. Tahap Search, yaitu mahasiswa dituntut berpikir untuk mengidentifikasi masalah dengan membaca, merumuskan masalah dalam bentuk pertanyaan dan menjawab pertanyaan tentang permasalahan. Mahasiswa mampu merumuskan permasalahan melalui wacana pada tahap Search.

Tahap Solve, yaitu mahasiswa menjawab pertanyaan (dari tahap search), membentuk hipotesis atau dugaan jawaban, mengumpulkan data dan menganalisis informasi yang berkaitan dengan permasalahan. Mahasiswa mampu membentuk hipotesis atau dugaan jawaban dari pertanyaan yang tercantum pada tahap Search. Selanjutnya dugaan jawaban tersebut akan dibuktikan melalui kegiatan pengamatan pada tahap Create.

Pada tahap Search dan Solve, mahasiswa dituntut melatih kemampuan berpikir terhadap suatu wacana pada tahap Search yang disajikan, membentuk hipotesis atau dugaan jawaban dan membuktikan teori/dugaan jawaban melalui kegiatan pengamatan. Hal tersebut ditunjukkan dengan kegiatan mahasiswa dalam proses pembelajaran menggunakan LKM berbasis Search, Solve, Create, and Share.Tahap Search dan Solve, selain melatih keterampilan berpikir mahasiswa tentang pemecahan masalah juga melatih mahasiswa berperilaku aktif dalam diskusi kelompok dan mengembangkan sikap ilmiah dalam pembelajaran.

Tahap Create, yaitu mahasiswa melakukan kegiatan pengamatan yang ada dalam wacana tahap Search, dimana mahasiswa melatih keterampilan dalam kegiatan praktikum. Mahasiswa juga dituntut menyajikan data hasil pengamatan sebagai solusi dari masalah berupa laporan, dokumentasi, dan media Power Point mengenai hasil pengamatan.

Tahap Share, dimana mahasiswa mengkomunikasikan hasil pengamatan secara tertulis berupa laporan dan lisan dengan mempresentasikan di depan kelas. Selain itu, mahasiswa juga dituntut mampu menerima umpan balik berupa kritik/sanggahan/ tanggapan dari dosen maupun mahasiswa lain saat mempresentasikan hasil pengamatan di depan kelas. Pada tahap Share ini, mahasiswa dilatih untuk mengemukakan pendapat dan membangkitkan minat bertanya tentang materi yang dipelajari.

Data keefektivan LKM selanjutnya yaitu keterampilan berpikir. Data keterampilan berpikir mahasiswa diambil dengan teknik observasi pada saat pembelajaran menggunakan LKM berbasis Search, Solve, Create, and Share. Berdasarkan hasil analisis, rata-rata persentase keterampilan berpikir yaitu $72,77 \%$ dengan kategori terampil. Slavin (2011) menyatakan strategi melatih kemampuan berpikir meliputi empat langkah yaitu menyatakan, mencari, mengevaluasi, dan menguraikan permasalahan. Keempat langkah yang diungkapkan Slavin tersebut sudah tergambar dalam indikator-indikator keterampilan berpikir yang diukur. Setiap indikator keterampilan berpikir mempunyai empat aspek yang merupakan penentuan skor pengukuran keterampilan berpikir. Berdasarkan analisis, rata-rata persentase keterampilan berpikir menunjukkan bahwa keterampilan berpikir mahasiswa dalam 
pembelajaran Ekologi Hewan menggunakan LKM berbasis Search, Solve, Create, and Share menunjukkan hasil yang baik dan LKM tersebut efektif terhadap keterampilan berpikir mahasiswa.

Model Search, Solve, Create, and Share berpendekatan pembelajaran problem solving, yang terkandung dalam LKM menjadikan mahasiswa aktif dalam rangka memecahkan masalah. LKM berbasis Search, Solve, Create, and Share menyajikan wacana sebagai permasalahan. Selanjutnya mahasiswa memperdalam pengetahuannya tentang apa yang diketahui dan bagaimana membuktikan teori secara berkelompok dalam rangka memecahkan masalah. Melalui diskusi dengan anggota kelompok yang heterogen memungkinkan mahasiswa untuk saling bertukar pikiran, mengemukakan pendapat dan melibatkan mahasiswa berperan aktif dalam pembelajaran.

Berdasarkan hasil analisis, rata-rata persentase aktivitas mahasiswa yaitu $74,87 \%$ dengan kategori aktif. Hal tersebut menunjukkan bahwa aktivitas mahasiswa dalam pembelajaran menggunakan LKM berbasis Search, Solve, Create, and Share menunjukkan hasil yang baik dan LKM tersebut efektif terhadap aktivitas mahasiswa. Dengan melihat data keefektivan LKM meliputi data hasil belajar, aktivitas, dan keterampilan berpikir, LKM berbasis Search, Solve, Create, and Share layak diterapkan pada pembelajaran Ekologi Hewan.

\section{KESIMPULAN}

Berdasarkan hasil penelitian dan pembahasan yang telah dijelaskan, maka peneliti dapat menarik kesimpulan sebagai berikut: (1) Lembar Kerja Mahasiswa berbasis Search, Solve, Create, and Share yang dikembangkan layak digunakan dalam mata kuliah Ekologi Hewan, berdasarkan penilaian ahli sebesar 76,96 \% dengan kategori layak, (2) Lembar Kerja Mahasiswa berbasis Search, Solve, Create, and Share efektif terhadap hasil belajar mahasiswa dalam pembelajaran dengan rata-rata nilai $N$-gain sebesar sebesar 0,65 dengan kategori sedang, (3) Lembar Kerja Mahasiswa berbasis Search, Solve, Create, and Share efektif terhadap keterampilan berpikir mahasiswa dalam pembelajaran dengan rata-rata persentase keterampilan berpikir yaitu $72,77 \%$ dengan kategori terampil, (4) Lembar Kerja Mahasiswa berbasis Search, Solve, Create, and Shareefektif terhadap aktivitas mahasiswa dalam pembelajaran dengan rata-rata persentase $74,87 \%$ dengan kategori aktif, (5) Berdasarkan kesimpulan yang telah dijelaskan maka ada beberapa saran yang dapat dikemukakan, diantaranya sebagai berikut, (6) Kepada dosen lainnya agar selalu mengembangkan LKM dengan menggunakan strategi dan model pembelajaran lainnya sesuai dengan perkembangan ilmu pengetahuan dan teknologi (IPTEK) untuk mata kuliah tertentu sehingga dapat membantu perkembangan kognitif dan kemampuan lainnya, dan (7) Perlu diadakan penelitian yang lebih lanjut tentang pengembangan LKM berbasis Search, Solve, Create, and Shareuntuk memperbanyak khasanah pengetahuan dalam meningkatkan hasil belajar.

\section{UCAPAN TERIMAKASIH}

Terimakasih kepada LP2M Institut Pendidikan Tapanuli Selatan yang telah memberikan dukungan finansial sehingga penelitian ini dapat terlaksana dengan baik. Terimakasih kepada reviewer yang telah ditunjuk oleh LP2M yang telah memberikan bimbingan dan arahan sehingga penelitian ini dapat terselesaikan dengan baik. 


\section{DAFTAR PUSTAKA}

Aqib, Zainal. 2013. Model-model, Media, dan Strategi Pembelajaran Kontekstual (Inovatif). Bandung: Yrama Widya.

Ariyati, Eka. 2010. Pembelajaran Berbasis Praktikum untuk Meningkatkan Kemampuan Berpikir Kritis Mahasiswa. Jurnal Matematika dan IPA Universitas Tanjungpura, 1(2) Tahun 2010.

Chen, Wen Haw. 2013. Applying ProblemBased Learning Model and Creative Design to Conic-Sections Teaching. International Journal of Education and Information Technologies, 3(7) Tahun 2013.

Chin, Christine. 1997. Promoting higher cognitive learning in science through a problem-solving approach. Journal National Institute of Education in Singapore, Vol. 1: 7-11

Choo, S. S. Y., J. I. Rotgans, E. H. J. Yew, \& Henk G. Schmidt. 2011. Effect of worksheet scaffolds on student learning in problembased learning. Health Science Education Article. Tersedia di http://springerlink.com/ [diakses 25-01-2014].

Departemen Pendidikan Nasional. 2008. Panduan Pengembangan Bahan Ajar. Jakarta: Departemen Pendidikan Nasional.

Gardner, Joel \& B.R. Belland. 2012. A Conceptual Framework for Organizing Active Learning Experiences in Biology Instruction. Journal Science Education Technology, (2012) 21: 465-475.

Hasruddin \& Salwa Rezeqi. 2012. Analisis Pelaksanaan Praktikum Biologi dan Permasalahannya di SMA Negeri Sekabupaten Karo. Jurnal Tabularasa PPS Unimed, 9(1) Tahun 2012.

Ibrahim, R \& N. Syaodih S.. 2003. Perencanaan dan Strategi Pembelajaran. Jakarta: Rineka Cipta.

Irwan. 2011. Pengaruh Pendekatan Problem Posing Model Search, Solve, Create And Share (SSCS) Dalam Upaya Meningkatkan
Kemampuan Penalaran Matematis Mahasiswa Matematika. Jurnal Penelitian Pendidikan, 12(1) Tahun 2011.

Johan, Henry. 2012. Pengaruh Search, Solve, Create and Share (SSCS) Problem Solving untuk Meningkatkan Kemampuan Mahasiswa dalam Merumuskan dan Memilih Kriteria Pemecahan Masalah pada Konsep Listrik Dinamis. Jurnal Exacta Pendidikan Matematika dan Sains, 10(2): 140142.

Khoirifah, S., E. Saptaningrum, \& J. Saefan. 2013. Pengaruh Pendekatan Problem Solving Model Search, Solve, Create and Share (SSCS) Berbantuan Modul Terhadap Kemampuan Berpikir Kritis Siswa Pada Pokok Bahasan Listrik Dinamis. Prosiding 2nd Lontar Physics Forum 2013. Semarang: IKIP PGRI Semarang.

Prastowo, A. 2012. Panduan Kreatif Membuat Bahan Ajar Inovatif. Yogyakarta. Diva Press.

Purwanto. 2011. Evaluasi Hasil Belajar. Yogyakarta: Pustaka Pelajar.Rahardi, 2006. Paduan Lengkap Menulsi Artikel, Feature, Dan Esai. Tanggerang: Kawan Pustaka.

Rustaman, N., Soedjojo D., Siroso A. Y, Yusnani A., Ruchji S., Diana R., \& Mimin N.K. 2003. Strategi Belajar Mengajar Biologi. Jakarta : Universitas Pendidikan Indonesia.

Setyosari, Punaji. 2010. Metode Penelitian Pendidikan dan Pengembangan. Jakarta: Pranada Media.

Sudijono, Anas. 2006. Pengantar Statistika Pendidikan. Jakarta: Raja Grafindo Persada.

Sugiyono. 2012. Metode Penelitian Kuantitatif, Kualitatif dan R\&D. Bandung: Alfabeta.

Wardani, Sri. 2008. Pengembangan Keterampilan Proses Sains dalam Pembelajaran Kromatografi Lapis Tipis melalui Praktikum Skala Mikro. Jurnal Inovasi Pendidikan Kimia, 2(2): 317-322. 